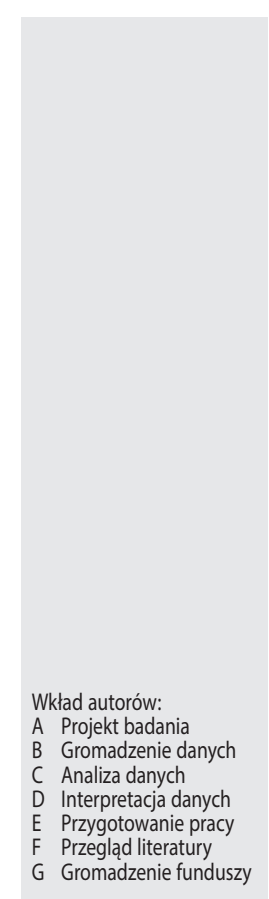

\title{
Ocena wpływu zmiany kształtu impulsu stymulującego na stymulację nerwu twarzowego u dzieci korzystających z implantu ślimakowego
}

\section{Assessment of the effectiveness of changing the shape of the stimulus pulse for facial nerve stimulation in cochlear implanted children}

\author{
Michał Karwat ${ }^{1 A-F}$, Adam Walkowiak ${ }^{1 A B D E}$, Artur Lorens ${ }^{1 A C-F}$, \\ Anita Obrycka ${ }^{1 A C-E}$, Henryk Skarżyński ${ }^{\text {ADE }}$ \\ ${ }^{1}$ Instytut Fizjologii i Patologii Słuchu, Światowe Centrum Słuchu, Zakład Implantów \\ i Percepcji Słuchowej, Warszawa/Kajetany \\ ${ }^{2}$ Instytut Fizjologii i Patologii Słuchu, Światowe Centrum Słuchu, Klinika Oto-Ryno- \\ Laryngochirurgii, Warszawa/Kajetany
}

\begin{abstract}
Streszczenie
Wprowadzenie: Niepożądana stymulacja nerwu twarzowego, występująca sporadycznie u użytkowników implantów ślimakowych, prowadzi do mimowolnego skurczu mięśni mimicznych twarzy wskutek rozpływu prądu stosowanego w celu wywołania wrażeń słuchowych. Wystąpienie pobudzenia nerwu twarzowego często prowadzi do konieczności ograniczenia poziomu stymulacji, co z kolei powoduje zbyt ciche słyszenie przez implant. Aby ograniczyć niepożądaną pozaakustyczną stymulację, firma Med-El zaproponowała modyfikację kształtu impulsów stymulujących.

Materiał i metody: Grupa badana liczyła 6 dzieci w wieku od 6 do 15 roku życia, użytkowników systemu implantu ślimakowego firmy Med-El. Do badania wybrano pacjentów, u których zaobserwowano pobudzenie nerwu twarzowego podczas stymulacji przez implant ślimakowy, a jednocześnie potrafiących subiektywnie określić wrażenie głośności za pomocą skali kategorialnej. U każdego z nich wykonano skalowanie głośności, prowadząc stymulację przez pojedynczą elektrodę. Badanie wykonano dla każdej aktywnej elektrody przy zastosowaniu standardowej stymulacji zarówno dwufazowej, jak i trójfazowej. Ponadto dla każdej stymulowanej elektrody oraz dla każdego rodzaju stymulacji wyznaczono próg wystąpienia pobudzenia nerwu twarzowego oraz subiektywną głośność dla uzyskanych wartości progowych. Na podstawie przeprowadzonego skalowania głośności ustawiono po dwa programy dla każdego pacjenta, jeden z wykorzystaniem stymulacji dwufazowej, a drugi z wykorzystaniem stymulacji trójfazowej. Wartości ładunku stymulującego dla poszczególnych elektrod implantu (nazywane poziomami MCL) zostały ustawione poniżej progu pobudzenia nerwu twarzowego, a jeśli nie występowało pobudzenie nerwu twarzowego, zostały ustalone na poziomie komfortowego słyszenia (bardzo głośno, ale nie za głośno). Następnie z zastosowaniem mowy jako sygnału testowego porównano wrażenie głośności w warunkach odsłuchu przez system implantu ślimakowego dla obu programów różniących się sposobem stymulacji oraz wartością ładunku wykorzystywanego do stymulacji.

Wyniki: Wartości progów wystąpienia podrażnienia nerwu twarzowego dla stymulacji trójfazowej były o 10,6 qu wyższe od wartości progów podrażnienia nerwu twarzowego dla stymulacji dwufazowej. Średnia wartość uzyskanych poziomów MCL dla standardowej stymulacji dwufazowej wynosiła 32 qu, natomiast wartość MCL dla stymulacji trójfazowej wyniosła 42,1 qu.

Wnioski: Niepożądana stymulacja nerwu twarzowego może być zredukowana przy pomocy zmiany kształtu bodźca stymulującego z dwufazowego na trójfazowy przy jednoczesnym uzyskaniu odpowiedniego wrażenia głośności dźwięków słyszanych za pośrednictwem systemu implantu ślimakowego.

Słowa kluczowe: implant ślimakowy • stymulacja trójfazowa • podrażnienie nerwu twarzowego
\end{abstract}

Adres autora: Michał Karwat, Zakład Implantów i Percepcji Słuchowej, Światowe Centrum Słuchu, Instytut Fizjologii i Patologii Słuchu, Kajetany, ul. Mokra 17, 05-830 Nadarzyn; e-mail: m.karwat@ifps.org.pl 


\section{Abstract}

Background: Unwanted stimulation of the facial nerve, which occurs occasionally in cochlear implant users, leads to involuntary contraction of the facial muscles as a result of the flow of current used to induce auditory sensations. The occurrence of facial nerve excitation often leads to reduction of stimulation levels, which finally causes too quiet hearing through the implant. In order to reduce the undesirable non-acoustic sensations, Med-El proposed stimulating pulses shape modification.

Material and methods: The study involved 6 children aged 6 to 15, users of the Med-El cochlear implant system. The study involved patients who showed facial nerve stimulation during stimulation by the cochlear implant, and able to subjectively determine the impression of loudness using a categorical scale. Loudness scaling was performed by conducting stimulation through a single electrode. The test was performed for each active electrode using both standard two-phase stimulation and three-phase stimulation. Moreover, for each stimulated electrode and for each type of stimulation, the threshold for the occurrence of facial nerve stimulation and the subjective loudness for the obtained threshold values were determined. Based on the loudness scaling, two programs were suggested for each patient, one using biphasic stimulation and one using triphasic stimulation. The values of the stimulating charge for the individual electrodes of the implant were set below the threshold of the facial nerve stimulation, and if there was no stimulation of the facial nerve, they were set at the level of comfortable hearing. Then, using speech as a test signal, the loudness sensation under listening conditions by the cochlear implant system was compared for both programs that differed in the method and value of the charge used for stimulation.

Results: The facial nerve irritation thresholds for the three-phase stimulation were 10.6 qu higher than the facial nerve irritation thresholds for the two-phase stimulation. The mean value of the MCL levels obtained for the standard biphasic stimulation was 32 qu, comparing to $42.1 \mathrm{qu}$ for the three-phase stimulation.

Conclusions: Unwanted stimulation of the facial nerve can be reduced by changing the stimulus shape from biphasic to triphasic while maintaining an appropriate loudness sensation of sounds heard through the cochlear implant system.

Key words: cochlear implant $\bullet$ triphasic pulse stimulation $\bullet$ facial nerve stimulation

\section{Wprowadzenie}

Podstawową zasadą działania systemu implantu ślimakowego jest stymulacja elektryczna zakończeń nerwu słuchowego w celu wywołania wrażeń akustycznych [1]. System składa się z dwóch części: pierwszej wszczepianej pod skórę podczas zabiegu chirurgicznego oraz drugiej zewnętrznego procesora mowy, który odbiera i odpowiednio koduje dźwięki. Proces dopasowania systemu implantu ślimakowego polega na odpowiednim doborze parametrów elektrostymulacji. Do najistotniejszych parametrów należą: wartość ładunku elektrycznego odpowiadająca progowi słyszenia (elektryczny próg słyszenia - THR) oraz maksymalna wartość ładunku odpowiadająca wrażeniu głośności określanemu, jako głośno, ale nie za głośno (poziom maksymalnej komfortowej głośności - MCL). Wartość ładunku charakteryzuje ładunek elektryczny płynący w jednym kierunku podczas impulsu stymulującego, czyli ładunek jednej fazy w przypadku dwufazowego impulsu stymulującego. Ładunek jednej fazy definiuje się jako iloczyn prądu stymulującego i czasu trwania tej fazy. Jednostką ładunku w układzie SI jest kulomb (C).

Zarówno MCL jak również THR wyznaczane są indywidualnie dla każdego pacjenta na podstawie badań psychofizycznych skalowania głośności, badań obiektywnych (elektrofizjologicznych), jak również wywiadu strukturalizowanego i badań dyskryminacji mowy. Określone tak poziomy wpisywane są do procesora i tworzą zbiór parametrów zwanych mapą pacjenta. Wyznaczona indywidualnie mapa pacjenta powinna zapewnić pacjentowi percepcję głośności charakterystyczną dla słuchu prawidłowego [2].

Jednym ze sporadycznie występujących skutków ubocznych stymulacji u osób korzystających z implantu ślimakowego jest niepożądane pobudzenie nerwu twarzowego. Prowadzi ono do mimowolnego skurczu mięśni mimicznych twarzy. Do wystąpienia pobudzenia nerwu twarzowego po implantacji mogą predysponować takie czynniki jak: otoskleroza, przebieg nerwu twarzowego w bezpośrednim sąsiedztwie miejsca stymulacji przez implant, hipoplazja nerwu słuchowego, malformacje struktur ucha wewnętrznego. Skutkami ubocznymi stymulacji nerwu twarzowego mogą być: drżenie oka, brody, policzka, uczucie pieczenia na języku, uczucie „przejścia prądu”. Niepożądaną stymulację nerwu twarzowego jak dotąd próbowano zniwelować za pomocą modyfikacji parametrów stymulacji [3]. Stosowano zmiany poszczególnych parametrów stymulacji w procesie dopasowywania procesora mowy takie jak:

1. Zastąpienie poziomów MCL przez poziomy nieznacznie niższe od progów pobudzenia nerwu twarzowego. Próg ten jest rozumiany jako najmniejsza wartość ładunku, która powoduje niepożądaną stymulację nerwu twarzowego. Takie podejście skutkuje najczęściej nieodpowiednią percepcją głośności dźwięków odbieranych przez implant - są one słyszane zbyt cicho, co w kontekście dźwięków mowy może utrudniać ich rozumienie.

2. Zwiększenie czasu trwania impulsu lub zwiększenie odstępów między fazowych, tzn. zwiększenie czasu pomiędzy kolejnymi składowymi impulsu. Takie zmiany mogą przełożyć się na pogorszenie percepcji dźwięków otoczenia oraz sygnału mowy słyszanych za pośrednictwem systemu implantu ślimakowego. Wpływ takiego postępowania na ograniczenie pobudzenia nerwu twarzowego zaobserwowano tylko u nielicznych pacjentów.

3. Wyłączenie elektrod, które wywołują niepożądane pobudzenie nerwu twarzowego. W zależności od liczby wyłączonych elektrod może to prowadzić do pogorszenia słyszenia, a co za tym idzie - pogorszenia rozumienia mowy [4]. W przypadku gdy podrażnienie nerwu twarzowego rejestrowane jest dla większości elektrod, takie postępowanie jest niemożliwe do zastosowania.

Zastosowanie wymienionych strategii postępowania było raportowane przez Smullen i wsp. [5]. Autorzy zastosowali zmniejszenie poziomów stymulacji lub dezaktywację 
elektrod, dzięki czemu uzyskali ograniczenie podrażnienia nerwu twarzowego u 39 z 44 pacjentów. Niestety uzyskane ograniczenie podrażnienia nerwu twarzowego odbyło się kosztem jakości słyszenia.

Przestrzenny rozpływ ładunku podczas stymulacji zależy w znacznym stopniu od impedancji tkanek w sąsiedztwie elektrody oraz położenia elektrod względem zakończeń nerwu słuchowego. Czynniki te różnią się u każdego pacjenta zależnie od warunków anatomicznych ucha wewnętrznego. Na rozpływ przestrzenny ładunku ma również wpływ kształt impulsu stymulującego.

Powszechnie stosowane impulsy dwufazowe (rycina 1a) są zrównoważone pod względem ładunku, składają się z dwóch przeciwstawnych biegunów, które następują po sobie, tak że ładunek ujemny niweluje ładunek dodatni, co pozwala uniknąć niekorzystnego zjawiska kumulacji ładunku [8].

Od kilku lat prowadzone są badania nad wykorzystaniem impulsów trójfazowych składających się z trzech kolejnych faz o naprzemiennych polaryzacjach. Typowy impuls trójfazowy (rycina 1b) składają się z dwóch ujemnych (katodowych) faz o tym samym czasie trwania i jednej dodatniej (anodowej) fazy o dwukrotnie dłuższym czasie trwania [4].

Na podstawie przeprowadzonych pomiarów elektromiograficznych (EMG) u czterech pacjentów Bahmer i Baumann [7] wykazali redukcję podrażnienia nerwu twarzowego przy zastosowaniu trójfazowego impulsu stymulującego w porównaniu do impulsu dwufazowego. Podrażnienie występowało dla wyższych poziomów ładunku, gdy do stymulacji wykorzystywany był impuls trójfazowy. Ponadto większy poziom ładunku przełożył się na zwiększenie poziomu głośności możliwej do uzyskania bez podrażnienia nerwu twarzowego.

Padilla i Landsberger [9] wykazali, że trójfazowy tryb stymulacji zmniejsza rozprzestrzenianie się ładunku, chociaż wielkość redukcji jest bardzo zmienna u badanych. Braun i wsp. [4] również wykazali skuteczność zastosowania impulsów trójfazowych u pacjentów z podrażnieniem nerwu twarzowego w procesie dopasowania procesora mowy. Po zmianie kształtu impulsu wykonano test dyskryminacji słów jednosylabowych dla poziomu prezentacji $65 \mathrm{~dB}$ i zaobserwowano poprawę wyniku z 28\% dla stymulacji standardowej na $40 \%$ dla stymulacji z wykorzystaniem impulsów trójfazowych.

Dotychczas przeprowadzone badania pokazują, że nowy sposób stymulacji może skutecznie redukować podrażnienie nerwu twarzowego. Wskazują również na potrzebę prowadzenia dalszych badań z udziałem większej liczby badanych. Zgodnie z wiedzą autorów nie opublikowano dotychczas badań nad zastosowaniem impulsów trójfazowych podczas dopasowania systemu implantu ślimakowego u dzieci.

\section{Cel}

Celem pracy jest ocena wpływu zmiany kształtu impulsu stymulującego z dwufazowego na trójfazowy na próg wystąpienia pobudzenie nerwu twarzowego u dzieci korzystających z implantu ślimakowego.

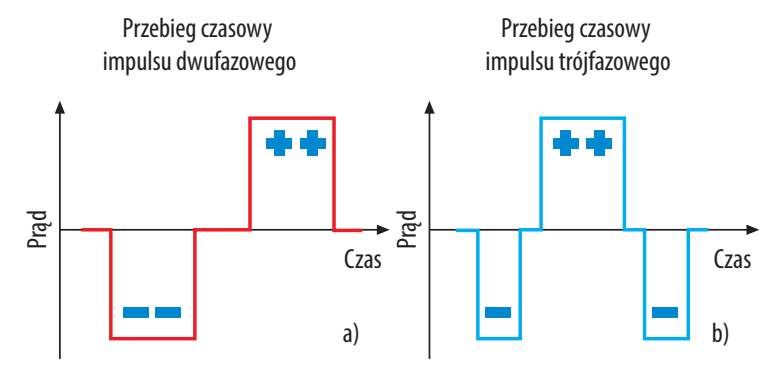

Rycina 1 a) Przebieg czasowy standardowego impulsu dwufazowego wykorzystywanego do stymulacji; b) przebieg czasowy dla nowego trójfazowego impulsu stymulującego

Figure 1 a) Time course of the standard biphasic stimulus pulse used for stimulation; b) time course of the new three-phase stimulating pulse

\section{Materiał i metody}

Niniejsza praca ma charakter retrospektywny - badacze analizowali istniejącą dokumentację medyczną zgromadzoną podczas standardowych sesji dopasowania procesora mowy. Grupa badana liczyła sześcioro dzieci w wieku od 6 do 15 lat. Wszyscy pacjenci byli użytkownikami implantu ślimakowego firmy Med-El, korzystali z procesorów mowy Opus2 lub Sonnet. Etiologia niedosłuchu pięcioro dzieci jest nieznana, u jednego pacjenta - genetyczna. Pięcioro pacjentów miało niedosłuch wrodzony, jedno dziecko - postępujący. U czworga badanych zdiagnozowano hipoplazję nerwu słuchowego, u jednego wadę wrodzoną ucha wewnętrznego (hypoplastyczny ślimak) i u jednego osyfikację ślimaka. W pięciu przypadkach do ślimaka wprowadzono wszystkie 12 kanałów, u jednego pacjenta wprowadzono 11 z 12 kanałów. Pomiary elektrycznie wywołanych złożonych potencjałów czynnościowych nerwu słuchowego u czworga dzieci miały nietypową morfologię zapisu - były trudne do jednoznacznej interpretacji, w pozostałych dwóch przypadkach zapisy te były prawidłowe dla wszystkich badanych elektrod. U wszystkich pacjentów obserwowano reakcje akustyczne na bodziec podawany podczas pomiaru. Charakterystykę grupy przedstawiono w tabeli 1 .

Do analizy zakwalifikowano pacjentów, u których zaobserwowano pobudzenie nerwu twarzowego podczas stymulacji przez implant, a jednocześnie potrafiących subiektywnie określić wrażenie głośności za pomocą skali kategorialnej (rycina 2). Na podstawie dokumentacji medycznej u każdego z nich wyznaczono próg wystąpienia pobudzenia nerwu twarzowego dla każdej elektrody, dla której występowało podrażnienie nerwu twarzowego w przypadku obu sposobów stymulacji. Próg ten jest rozumiany jako najmniejsza wartość ładunku, która powoduje niepożądaną stymulację nerwu twarzowego. Ponadto wykonano badanie skalowania głośności dla każdej aktywnej elektrody przy zastosowaniu zarówno standardowej stymulacji dwufazowej, jak i stymulacji trójfazowej.

W oparciu o wskazania dziecka na kategorialnej skali głośności (rycina 2) zaproponowano po dwa programy: jeden z wykorzystaniem standardowej stymulacji dwufazowej, drugi z wykorzystaniem nowego trójfazowego impulsu. Poziomy MCL dla poszczególnych elektrod zostały ustawione nieznacznie poniżej wyznaczonych wartości progowych 
Tabela 1. Specyfikacja grupy badanej

Table 1. Specification of the research group

\begin{tabular}{|c|c|c|c|c|c|c|c|c|c|c|c|}
\hline$\frac{\text { ঠे }}{\text { हू }}$ & $\frac{\underline{d}}{\underline{\alpha}}$ & $\begin{array}{l}\frac{\text { 응 }}{\circ} \\
\frac{0}{\stackrel{0}{ }}\end{array}$ & 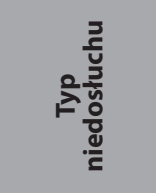 & 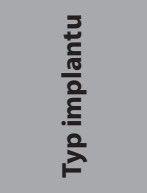 & 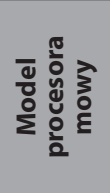 & 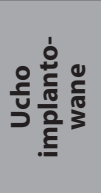 & 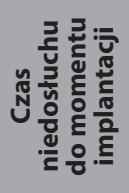 & 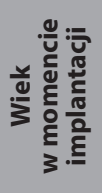 & 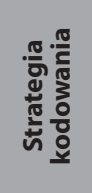 & 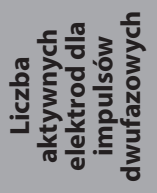 & 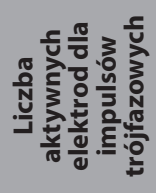 \\
\hline 1 & $\mathrm{~m}$ & nieznana & wrodzony & Synchrony & Sonnet & lewe & 3 & 3 & FS4 & 12 & 12 \\
\hline 2 & $\mathrm{~m}$ & genetyczna & wrodzony & Concerto & Sonnet & lewe & 7 & 7 & FS4 & 12 & 12 \\
\hline 3 & $\mathrm{~m}$ & nieznana & wrodzony & Pulsar & Opus2 & prawe & 1 & 1 & HDCIS & 8 & 8 \\
\hline 4 & $\mathrm{~m}$ & nieznana & wrodzony & Sonata & Sonnet & prawe & 1 & 1 & HDCIS & 5 & 8 \\
\hline 5 & $\mathrm{~m}$ & nieznana & postępujący & Sonata & Opus2 & lewe & 5 & 10 & FS4 & 11 & 11 \\
\hline 6 & k & nieznana & wrodzony & $\begin{array}{c}\text { Synchrony } \\
\text { PIN }\end{array}$ & Sonnet & prawe & 1,6 & 1,6 & FS4 & 12 & 12 \\
\hline
\end{tabular}

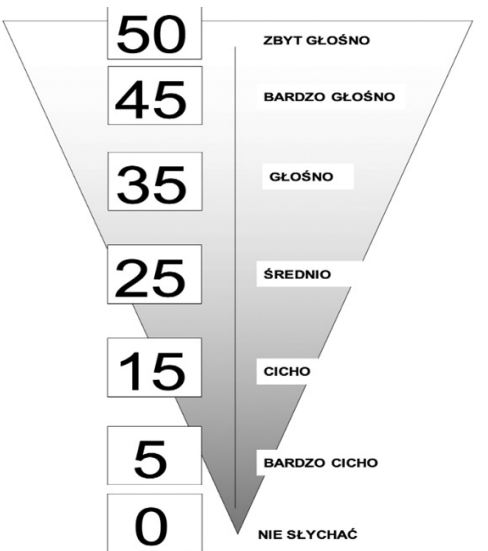

Rycina 2. Kategorialna skala głośności wykorzystywana w badaniach

Figure 2. Categorical loudness scale used in research

pobudzenia nerwu twarzowego. Jeśli podczas stymulacji na danej elektrodzie nie występowało podrażnienie nerwu twarzowego, wartości ładunku zostały ustalone na poziomie maksymalnego komfortowego słyszenia (głośno, ale nie za głośno) w oparciu o wskazania dziecka na skali kategorialnej. Następnie z zastosowaniem mowy jako sygnału testowego porównano wrażenie głośności w warunkach odsłuchu przez system implantu ślimakowego dla obu programów różniących się kształtem impulsu stymulującego (tabela 1).

W celu oceny wpływu zmiany rodzaju impulsu stymulującego $\mathrm{z}$ dwufazowego na trójfazowy na próg wystąpienia pobudzenie nerwu twarzowego porównano uzyskane wartości progów. Do porównania wykorzystano test $t$-Studenta. Przyjęto poziom istotności $\alpha<0,05$. Przeprowadzono także analizę wartości ładunków uzyskanych w procesie dopasowania procesora mowy dla poszczególnych elektrod, dla obu sposobów stymulacji.

\section{Wyniki}

Dla stymulacji dwufazowej o poziomach poniżej poziomów komfortowego słyszenia podrażnienie nerwu twarzowego wystąpiło średnio dla 10 z 12 elektrod sytemu. U czterech pacjentów zaobserwowano je na wszystkich 12 elektrodach, a u dwóch pozostałych podrażnienie zaobserwowano odpowiednio na 5 z 12 oraz 9 z 9 aktywnych elektrod.

Dla stymulacji trójfazowej poniżej poziomów komfortowego słyszenia podrażnienie wystąpiło tylko u jednego pacjenta na jednej z 12 elektrod, dla pozostałych nie zaobserwowano podrażnienia.

Średnia wartość uzyskanych poziomów MCL dla standardowej stymulacji dwufazowej wynosiła 32 qu, natomiast wartość MCL dla stymulacji trójfazowej wyniosła 42,1 qu. Różnica między poziomami MCL wyniosła zatem średnio 10,1 qu (gdzoe qu jest jednostką ładunku przyjętą przez firmę Med-El, $1 \mathrm{qu}=1 \mathrm{nC}$ ).

Średnie wartości progów pobudzenia nerwu twarzowego dla stymulacji dwufazowej istotnie różniły się od wartości tych progów dla stymulacji trójfazowej $(t(66)=14,25$; $p<0,001)$. Wartości progów wystąpienia podrażnienia nerwu twarzowego dla stymulacji trójfazowej były o 10,6 qu wyższe od wartości progów podrażnienia nerwu twarzowego dla stymulacji dwufazowej (rycina 3).

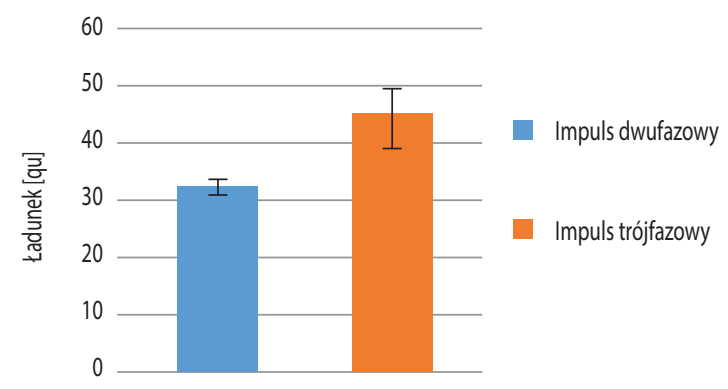

Rycina 3. Rycina 3. Uśrednione wartości progu podrażnienia nerwu twarzowego dla wszystkich pacjentów oraz aktywnych elektrod

Figure 3. Average values of the irritation threshold of the facial nerve for all patients and active electrodes 


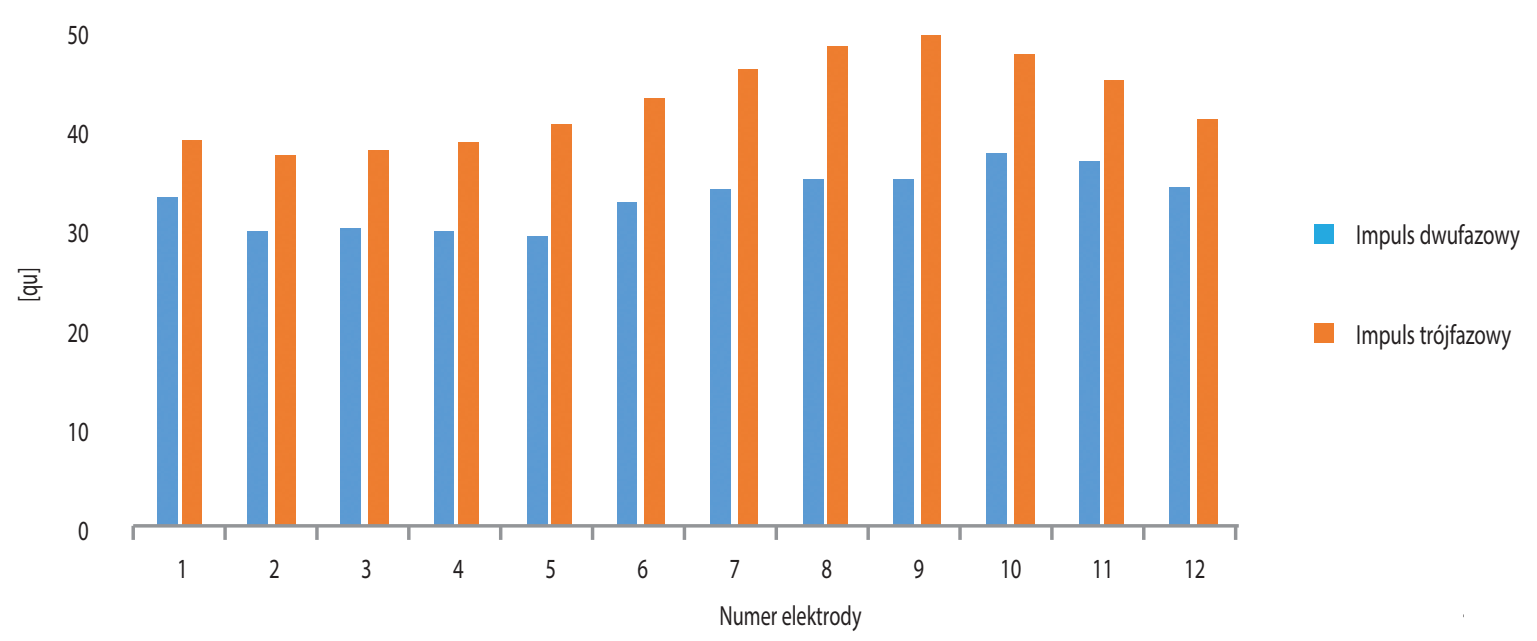

Rycina 4. Porównanie średnich wartości MCL (wykorzystanych do zaprogramowania procesora mowy) dla poszczególnych elektrod z wykorzystaniem obu sposobów stymulacji

Figure 4. Comparison of mean MCL values (used to program the speech processor) for individual electrodes using both stimulation methods

Średnie wartości MCL uzyskane w procesie dopasowania procesora mowy (użyte do zaprogramowania procesora) były większe dla stymulacji trójfazowej niż wartości uzyskane dla standardowej stymulacji (rycina 4). Przełożyło się to również na uzyskanie wrażenia zwiększonej głośności dźwięków słyszanych przez implant. W przypadku programu z wykorzystaniem stymulacji trójfazowej głośność dźwięków zbliżona była do kategorii „średnio” lub „głośno”, dla stymulacji dwufazowej była określona jako kategoria „cicho”. Dobrane parametry stymulacji nie powodowały podrażnienia nerwu twarzowego przy odsłuchu przez implant (tabela 2).

\section{Dyskusja}

W niniejszym badaniu wykazano, że zmiana rodzaju impulsu z dwufazowego na trójfazowy pozwala na zwiększenie progu wystąpienia podrażnienia nerwu twarzowego. Średnia wartość progu podrażnienia dla wszystkich aktywnych elektrod była o $29,4 \%$ większa dla stymulacji trójfazowej.

Tabela 2. Wartości MCL użyte dla poszczególnych elektrod oraz pacjentów do zaprogramowania procesora mowy dla obu sposobów stymulacji

Table 2. MCL values used for individual electrodes and patients to program the speach processor for both stimulation methods

\begin{tabular}{|c|c|c|c|c|c|c|c|c|c|c|c|c|c|}
\hline 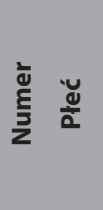 & 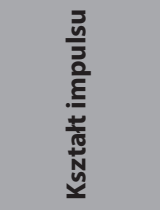 & 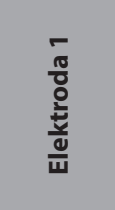 & 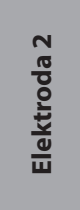 & 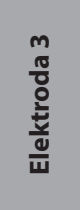 & 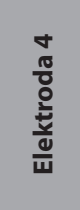 & 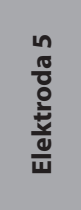 & 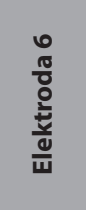 & 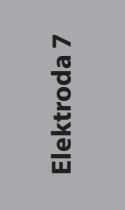 & 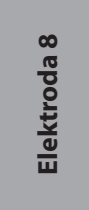 & 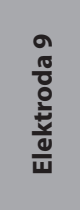 & 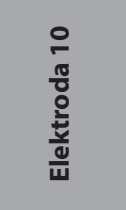 & $\begin{array}{l}= \\
\frac{\pi}{0} \\
\frac{0}{0} \\
\frac{0}{4} \\
\frac{10}{4}\end{array}$ & $\begin{array}{l}\text { N } \\
\frac{\pi}{8} \\
\frac{0}{0} \\
\frac{0}{2} \\
\frac{1}{4}\end{array}$ \\
\hline 1 & dwufazowy & 51,09 & 50,68 & 50,68 & 50,88 & 52,2 & 52,2 & 54,5 & 53,02 & 53,76 & 53,33 & 53,36 & 53,33 \\
\hline $\mathrm{m}$ & trójfazowy & 58,39 & 57,92 & 57,92 & 58,15 & 59,65 & 59,65 & 64,15 & 64,28 & 64,66 & 64,66 & 64,7 & 64,66 \\
\hline \multirow{2}{*}{2} & dwufazowy & 14,44 & 14,51 & 14,45 & 15,72 & 18,15 & 20 & 21,67 & 21,18 & 23,84 & 27,83 & 32,95 & 33,1 \\
\hline & trójfazowy & 20,44 & 21,6 & 22,33 & 24,3 & 28,05 & 28,66 & 31,44 & 34,1 & 35,07 & 36,28 & 37,89 & 38,22 \\
\hline \multirow{2}{*}{$3 \mathrm{~m}$} & dwufazowy & $\begin{array}{c}\text { nie- } \\
\text { aktywna }\end{array}$ & 22,19 & 21,03 & 18,43 & 16,52 & 28,84 & 32,97 & 41,15 & 35,18 & $\begin{array}{c}\text { nie- } \\
\text { aktywna }\end{array}$ & $\begin{array}{c}\text { nie- } \\
\text { aktywna }\end{array}$ & $\begin{array}{c}\text { nie- } \\
\text { aktywna }\end{array}$ \\
\hline & trójfazowy & $\begin{array}{c}\text { nie- } \\
\text { aktywna }\end{array}$ & 24,25 & 23,66 & 22,67 & 22,69 & 31,96 & 41,69 & 51,71 & 58,62 & $\begin{array}{c}\text { nie- } \\
\text { aktywna }\end{array}$ & $\begin{array}{c}\text { nie- } \\
\text { aktywna }\end{array}$ & $\begin{array}{c}\text { nie- } \\
\text { aktywna }\end{array}$ \\
\hline $\mathrm{m}$ & dwufazowy & 47,58 & 43,79 & 46,08 & 45,07 & 39,03 & 44,84 & 41,96 & 45,79 & 47,01 & 45,81 & 48,58 & 51,87 \\
\hline & trójfazowy & 52 & 55,92 & 57,6 & 59,65 & 62,65 & 66,47 & 67,95 & 66,82 & 67,74 & 62,67 & 55,91 & 53,15 \\
\hline \multirow{2}{*}{$5 \mathrm{~m}$} & dwufazowy & 15,28 & 15,28 & 16,05 & 17,48 & 18,24 & 18,82 & $\begin{array}{c}\text { nie- } \\
\text { aktywna }\end{array}$ & 18,26 & 18,26 & 16,33 & 15,86 & 15,86 \\
\hline & trójfazowy & 19,94 & 20,54 & 20,94 & 22,14 & 23,11 & 23,84 & $\begin{array}{c}\text { nie- } \\
\text { aktywna }\end{array}$ & 23,83 & 23,13 & 21,95 & 21,31 & 20,69 \\
\hline \multirow{2}{*}{6} & dwufazowy & 34,79 & 34,55 & 34,55 & 34,55 & 34,67 & 34,55 & 34,55 & 34,55 & 34,55 & 34,55 & 34,55 & 34,55 \\
\hline & trójfazowy & 47,13 & 46,81 & 48,22 & 49,27 & 50,91 & 52,27 & 53,83 & 53,83 & 53,83 & 53,83 & 53,83 & 53,83 \\
\hline
\end{tabular}


Zwiększenie progu wystąpienia podrażnienia nerwu twarzowego pozwoliło w procesie doboru parametrów stymulacji na zwiększenie wartości MCL. Średnia wartość ładunku użytego stymulacji dwufazowej wynosiła 32 qu, a dla stymulacji trójfazowej 42,1 qu. Zmiana tych parametrów stymulacji przełożyła się również na zwiększenie subiektywnego odczucia głośności dla dźwięków słyszanych za pomocą systemu implantu ślimakowego. Przed zastosowaniem zmian u badanych głośność określano kategorią „cicho”, a po zmianie kategoriami „średnio” lub „głośno”. Jest to pierwsza praca dotycząca zastosowania oraz oceny wpływu nowego trójfazowego impulsu stymulującego na próg wystąpienia pobudzenia nerwu twarzowego wyłącznie w grupie pediatrycznej i z tego powodu nie wykonano testu dyskryminacji słów jednosylabowych. Nasze wyniki badań można porównać z obserwacjami innych badaczy prowadzonymi głównie w grupach pacjentów dorosłych lub mieszanych.

Wyniki przeprowadzonych przez nas badań są bardzo zbliżone do wyników opublikowanych przez Braun, Walkera i wsp. [2]. Przeprowadzili oni podobne badania na grupie 14 osób, z czego u czworga pacjentów pediatrycznych i u 10 dorosłych. Średnie wartości MCL dla wszystkich elektrod wynosiły odpowiednio 51,12 qu dla impulsu trójfazowego oraz 36,37 qu dla impulsu dwufazowego. W 90\% przypadków udało się wyeliminować podrażnienie nerwu twarzowego. U 12 pacjentów przeprowadzono również test dyskryminacji słów jednosylabowych. Słowa były prezentowane w ciszy na poziomie $65 \mathrm{~dB}$ SPL. Stopień dyskryminacji mowy wzrósł z 28\% dla stymulacji dwufazowej do $40 \%$ dla stymulacji trójfazowej. Zastosowanie impulsów trójfazowych pozwoliło autorom na wyeliminowanie podrażnienia nerwu twarzowego w większości przypadków oraz na poprawę rozumienia mowy w badaniach dyskryminacji słów jednosylabowych.

Przeprowadzone przez nas badania są również zgodne z wynikami uzyskanymi przez Schatzera [10] w grupie 16 dorosłych pacjentów: wykazano, że podczas stymulacji dwufazowej dla subiektywnego odczucia głośności w kategoriach „cicho” lub „średnio” zaobserwowano podrażnienie nerwu twarzowego. U jednego z pacjentów nie zaobserwowano zmiany percepcji głośności przy zmianie kształtu impulsu stymulującego na trójfazowy. Jednak u pozostałych 15 pacjentów zmiana kształtu impulsu stymulującego na trójfazowy pozwoliła na zwiększenie poziomów MCL, co przełożyło się również na poprawę subiektywnego odczucia głośności. Dobrane parametry pozwoliły również na całkowite wyeliminowanie podrażnienia nerwu twarzowego u tych pacjentów. Po zastosowaniu zmian średni poziom MCL dla stymulacji trójfazowej wzrósł o 17\%. Wynik ten jest również jest zbliżony do wyniku przedstawionego w naszej pracy (wzrost o 29,4\%).

Alhabib i wsp. [11] przeprowadzili badania wypływu zmiany kształtu impulsu stymulującego na podrażnienie nerwu twarzowego oraz rozumienie mowy. Grupa badana liczyła 11 pacjentów. Stosując impulsy trójfazowe oraz wyłączając niektóre elektrody, wyeliminowano podrażnienie nerwu twarzowego u wszystkich pacjentów. Zmiana kształtu impulsu na trójfazowy pozwoliła również na zwiększenie wartości MCL przy jednoczesnym braku podrażnienia nerwu twarzowego. Wartości MCL dla impulsu trójfazowego wyniosły $36,62 \pm 1,63 \mathrm{qu}$, natomiast dla impulsu dwufazowego $31,58 \pm 2,5$ qu. Przedstawione wartości MCL są bardzo zbliżone do wartości otrzymanych w naszych badaniach w grupie pediatrycznej. Wynikiem przeprowadzonych zmian był również wzrost stopnia dyskryminacji słów jednosylabowych dla stymulacji trójfazowej: $75,25 \% \pm 26,13$, a dla stymulacji dwufazowej: $58,25 \% \pm 26,13$.

Abdelhamed [12] w swojej pracy przedstawił wyniki dla grupy pięciu pacjentów z podrażnieniem nerwu twarzowego, u których poprzednie modyfikacje parametrów stymulacji, takie jak: zmniejszenie ładunku, zmiana strategii kodowania, zmiana szerokości impulsu oraz zmiana szybkości stymulacji, nie przyniosły efektu. Zmiana kształtu impulsu stymulującego na trójfazowy pozwoliła wyeliminować podrażnienie nerwu twarzowego w $100 \%$. Średnie wartości MCL dla stymulacji trójfazowej były o 5 qu do 10 qu większe w stosunku do dwufazowej. W wynikach badań przedstawionych w naszej pracy średnia wartość MCL dla stymulacji trójfazowej była większa o 10,1 qu niż wartość MCL dla stymulacji dwufazowej. Wykonano również badania audiometrii progowej w polu swobodnym przed zastosowaniem i po zastosowaniu zmian. Progi uzyskane w badaniu różniły się o $10 \mathrm{~dB}$ na korzyść stymulacji trójfazowej.

W powyższych pracach wykazano, że zmiana kształtu impulsu stymulującego ze standardowego dwufazowego na trójfazowy powoduje zwiększanie progu wystąpienia podrażnienia nerwu twarzowego, co pozwala na zwiększanie wartości MCL. Co z kolei przekłada się na poprawę subiektywnego odczucia głośności dźwięku słyszanego za pośrednictwem systemu implantu ślimakowego bez skutków ubocznych stymulacji w postaci podrażnienia nerwu twarzowego. Wykazano również korzystny wpływ zmiany kształtu impulsu stymulującego na wyniki uzyskiwane w teście dyskryminacji mowy. Wszystkie wyżej wymienione czynnik prowadzą do poprawy percepcji oraz komfortu korzystania $\mathrm{z}$ implantu ślimakowego przez tych użytkowników.

\section{Wnioski}

Zmiana sposobu stymulacji u dzieci na trójfazową powoduje zwiększenie progu wystąpienia pobudzenia nerwu twarzowego. Jednoczenie pozwala na zwiększenie subiektywnego odczucia głośności dla wartości MCL, które nie powodują skutków ubocznych stymulacji w postaci niepożądanego pobudzenia nerwu twarzowego. Zastosowanie stymulacji trójfazowej w procesie dopasowania procesora mowy może zatem pozwolić na wyeliminowanie podrażnienia nerwu twarzowego bez zmniejszenia odczuwanej głośności oraz bez konieczności wyłączania poszczególnych elektrod.

\section{Piśmiennictwo}

1. Pieczykolan A, Kruszyńska M, Wiśniewski T, Lorens A i wsp. Dopasowanie systemu implantu ślimakowego - podstawy teoretyczne. Now Audiofonol, 2016; 5(4): 24-35.
2. Boyd PJ. Effects of programming threshold and maplaw settings on acoustic thresholds and speech discrimination with the MED-EL COMBI 40+ cochlear implant. Ear Hear, 2006; 27(6): 608-18. 
3. Berrettini S, De Vito A, Bruschini L, Passetti S, Forli F. Facial nerve stimulation after cochlear implantation: our experience. Acta Otorhinolaryngol Ital, 2011; 31(1): 11-6.

4. Braun K, Walker K, Sürth W, Löwenheim H, Tropitzsch A. Triphasic pulses in cochlear implant patients with facial nerve stimulation. Otol Neurotol, 2019; 40(10): 1268-77.

5. Smullen JL, Polak M, Hodges AV, Payne SB i wsp. Facial nerve stimulation after cochlear implantation. Laryngoscope, 2005; 115(6): 977-82.

6. Bahmer A, Polak M, Baumann U. Recording of electrically evoked auditory brainstem responses after electrical stimulation with biphasic, triphasic and precision triphasic pulses. Hear Res, 2010; 259(1-2): 75-85.

7. Bahmer A, Baumann U. The underlying mechanism of preventingfacial nerve stimulation by triphasic pulse stimulation in cochlearimplant users assessed with objective measure. Otol Neurotol, 2016; 37: 1231-7.
8. van Wieringen A, Macherey O, Carlyon RP, Deeks JM, Wouters J. Alternative pulse shapes in electrical hearing. Hear Res, 2008; 242(1-2): 154-63.

9. Landsberger DM, Padilla M, Srinivasan AG. Reducing current spread using current focusing in cochlear implant users, Hear Res, 2012; 284(1-2): 16-24.

10. Schatzer R, Van der Heying, Muller J i wsp. Selective suppression of facial nerve activation in CI patients with triphasic stimulation. 13th International Conference on Cochlear Implants and other Implantable Auditory Technologies, Munich; 2014.

11. Alhabib SF, Abdelsamad Y, Yousef M i wsp. Performance of cochlear implant recipients fitted with triphasic pulse patterns. Eur Arch Otorhinolaryngol, 2021; 278(9): 3211-16, https://doi. org/10.1007/s00405-020-06382-0 [dostęp: 3.01.2022].

12. Abdelhamed M. Evaluation of the triphasic pulse stimulation in eliminating facial nerve stimulation in cochlear implant recipients. Glob J Otolaryngol, 2019; 19(2): 556007. 